\title{
Identification of the traditional and non-traditional sulfate-reducing bacteria associated with corroded ship hull
}

\author{
Kiana Alasvand Zarasvand ${ }^{1} \cdot$ V. Ravishankar Rai ${ }^{1}$
}

Received: 17 June 2016/Accepted: 24 August 2016/Published online: 12 September 2016

(c) The Author(s) 2016. This article is published with open access at Springerlink.com

\begin{abstract}
Pitting corrosion due to microbial activity is the most severe type of corrosion that occurs in ship hull. Since biogenic sulfide produced by sulfate-reducing bacteria $(\mathrm{SRB})$ is involved in the acceleration of pitting corrosion of marine vessels, so it is important to collect information about SRB community involved in maritime vessel failure. We investigated the SRB community on corroded hull portion of the ship. With the use of common cultural method and $16 \mathrm{~S}$ rDNA sequencing, ten bacteria with sulfate reduction ability were isolated and identified. They belonged to both traditional (Desulfovibrio, Desulfotomaculum) and non-traditional (Citrobacter) sulfate-reducing bacteria. All the isolates were able to produce a high amount of sulfide. However, only traditional isolates were showing the amplification for the SRB-specific gene, $d s r A B$. Further studies on corrosion potential of these two groups of bacteria showed that in spite of high sulfide and biofilm production by non-traditional SRB, they are less aggressive towards the mild steel compare to the traditional group.
\end{abstract}

Keywords Phylogeny - SRB - Ship hull $\cdot d s r A B$. Corrosion

\section{Introduction}

Microbiologically influenced corrosion (MIC) is an electrochemical process, where the presence and activity of microorganisms accelerate the kinetics of corrosion

V. Ravishankar Rai

raivittal@gmail.com

1 Department of Studies in Microbiology, University of Mysore, Mysore 570006, India process (Beech and Sunner 2004). MIC is well documented in many industries, including ship industry, offshore oil and gas production, power plants, and coastal industrial plants (Licina and Cubicciotti 1989; Bodtker et al. 2008; Inbakandan et al. 2010).

Maritime vessels are prone to MIC, as they continuously get exposed to seawater which contains a large number of different microbes. The impairment of metal function due to microbial bioactivity leads to substantial economical loss for ship industries (Schultz et al. 2011). The corrosion of ship hulls increases the surface roughness which consequently enhances the frictional drag. This reduces the ship speed which could be compensated by higher fuel consumption to maintain the required speed. Currently, antifouling paint (paints containing biocides) is being employed to prevent microbial corrosion on ship (Almeida et al. 2007). However, the effective action of antifouling paint depends on many factors, such as temperature, salinity and acidity of water, type of metal, and type of microorganism.

Microbial community on ship hull consists of rich and functionally diverse group of bacteria (Inbakandan et al. 2010). Aerobic and anaerobic bacteria, fungi, and yeast are reported to be responsible for the corrosion of ship hull (Wade et al. 2011). Though many bacteria have been isolated from ship hull, information regarding sulfate-reducing bacteria (SRB) communities from hull of ship has not been recorded so far.

SRB are the most troublesome groups of microorganisms involved in MIC in shipping industry (Tsinker 2004). Hydrogen sulfide, an end product of SRB metabolism, reacts with metal ion to form less soluble metal sulfide which later gets deposited on the metal surface and accelerates the process of pitting corrosion. Pitting corrosion reduces hull thickness which consequently affects the 
strength performance of the hull structure and results in other forms of failures (Jakubowski 2011). Therefore, due to the importance of this group of bacteria in MIC, in the present study, an attempt was made to isolate the sulfatereducing bacteria from the biofilm formed on the corroded ship hull.

\section{Materials and methods}

\section{Sample collection}

Total five metal pieces with typical signs of corrosion (metal with pits and black deposits) caused by the activity of SRB was harvested from the underwater portion of corroded hull of fishing vessel in Goa, India, as this part is the most vulnerable part of ship for corrosion. Samples were collected from five different depths (sample number one which was the uppermost sample taken from below the waterline and sample number five was the lowermost one) when a ship was in dry-docking. Each sample was washed three times with sterile phosphate buffer solution to remove any loosely attached bacteria. Sessile bacteria were scraped off from each metal piece and transferred to $50 \mathrm{ml}$ sterile glass container filled with enrichment medium. Then, bottles were transferred to the laboratory and incubated anaerobically at $25^{\circ} \mathrm{C}$ for 1 week. The growth of SRB was indicated by the turbidity of culture medium and the production of $\mathrm{H}_{2} \mathrm{~S}$. The Postgate's $\mathrm{B}$ medium was used as enrichment medium which contained $5 \mathrm{ml} 70 \%$ sodium lactate, $0.5 \mathrm{~g} \mathrm{KH}_{2} \mathrm{PO}_{4}, 1.0 \mathrm{~g} \mathrm{NH}_{4} \mathrm{Cl}, 1.0 \mathrm{~g} \mathrm{Na}_{2} \mathrm{SO}_{4}, 2.0 \mathrm{~g}$ $\mathrm{MgSO}_{4} \cdot 7 \mathrm{H}_{2} \mathrm{O}, 1.0 \mathrm{~g}$ yeast extract, $0.1 \mathrm{~g} \mathrm{CaCl}_{2} \cdot 2 \mathrm{H}_{2} \mathrm{O}, 0.5 \mathrm{~g}$ $\mathrm{FeSO}_{4} \cdot 7 \mathrm{H}_{2} \mathrm{O}$, and $20 \mathrm{~g} \mathrm{NaCl}$ in 11 of distilled water $(\mathrm{pH}$ 7.5-8.0). Sodium thioglycolate $(0.1 \mathrm{~g})$ and vitamin $\mathrm{C}$ $(0.1 \mathrm{~g})$ were added to the media as reducing agents. Resazurin ( $1 \mathrm{mg} / \mathrm{l})$ also was added to notify the anoxic condition.

\section{Isolation procedures}

The isolation of bacteria from enriched sample was carried out by the serial dilution of enrichment culture $(1 \mathrm{ml})$ in deaerated water. Hundred microliter aliquot from $10^{-4}$ to $10^{-6}$ dilutions were spread uniformly over the Postgate's B agar plate. The plates were incubated in the dark at $25^{\circ} \mathrm{C}$ under anaerobic conditions until black colored colonies appeared on the plates (7-10 days). Anaerobic condition generated in an anaerobic jar with Anaerogas Pack (HiMedia, India). The development of anaerobic condition was confirmed using Anaero indicator (HiMedia, India). Later, well-separated black colonies were picked up randomly and streaked on new plates until getting pure bacterial culture. The purity of the culture was checked with microscopic observation.

\section{DNA extraction and PCR amplification}

The genomic DNA was extracted from a single colony of bacteria using the HiPurA bacterial genomic DNA purification kit (HiMedia, India). 16S rDNA locus was amplified by universal primer pairs, 27F and $1492 \mathrm{R}$ (Lane 1991). The PCR condition included an initial denaturation of $94{ }^{\circ} \mathrm{C}$ for $7 \mathrm{~min}$ followed by 35 cycles of $94{ }^{\circ} \mathrm{C}$ for $1 \mathrm{~min}$, $56{ }^{\circ} \mathrm{C}$ for $1 \mathrm{~min}$, and $72{ }^{\circ} \mathrm{C}$ for $1 \mathrm{~min}$ with a final extension at $72{ }^{\circ} \mathrm{C}$ for $7 \mathrm{~min}$. The amplification of $\sim 1.9$-kb fragment of the dissimilatory sulfite reductase gene $(\operatorname{sr} A B)$ also was carried out using DSR1-F and DSR4-R primers (Wagner et al. 1998). The thermal cycling conditions for amplification were an initial denaturation step $\left(7 \mathrm{~min}, 94^{\circ} \mathrm{C}\right.$ ) followed by 30 cycles of denaturation $\left(45 \mathrm{~s}, 94^{\circ} \mathrm{C}\right)$, annealing $\left(45 \mathrm{~s}, 57^{\circ} \mathrm{C}\right)$, and extension $\left(1 \mathrm{~min}, 72^{\circ} \mathrm{C}\right)$ and one terminal extension step $\left(7 \mathrm{~min}, 72^{\circ} \mathrm{C}\right)$. In amplification of $d s r A B$ gene, a negative control reaction with Escherichia coli (MTCC 40) DNA was included.

\section{Sequence analysis and phylogenetic analyses}

Sequencing of the amplified products was carried out by Sanger's dideoxynucleotide sequencing method. The sequences were compared with sequences stored in GenBank using the BLAST (basic local alignment search tool) algorithm. Subsequently, a phylogenetic tree was constructed using the neighbor-joining algorithms with the Molecular Evolutionary Genetics Analysis software (MEGA 6).

\section{Sulfate and sulfide measurement}

To measure the amount of hydrogen sulfide produced by bacteria, Cord-Ruwisch (1985) method has been used. After dissolving of precipitated $\mathrm{FeS}$ by replacing $5 \%$ of culture media with $4 \mathrm{M} \mathrm{HCl}, 0.05 \mathrm{ml}$ of bacterial culture was mixed with $1.95 \mathrm{ml}$ of copper reagent [mixture of HCI $(50 \mathrm{mM})$ and $\left.\mathrm{CuSO}_{4}(5 \mathrm{mM})\right]$, and then, OD was measured at $480 \mathrm{~nm}$. The $0.05 \mathrm{ml}$ sterile media mixed with $1.95 \mathrm{ml}$ $\mathrm{HCl}(50 \mathrm{mM})$ were used as blank. Later, the result was compared with the standard hydrogen sulfide plot. Sulfate was measured by the $\mathrm{BaSO}_{4}$ gravimetric method (Gilcreas 1965), where $20 \mathrm{ml}$ of bacterial culture was mixed with $5 \mathrm{ml}$ of conditioning reagent, and then, the volume has been brought to $100 \mathrm{ml}$ by distilled water. Later, a spoonful of barium chloride crystal was added to each sample, and after, mixing OD was measured at $420 \mathrm{~nm}$. For the control, sterile media have been used. Later, the result was compared with the standard sulfate plot. 


\section{Biofilm formation}

To study the biofilm formation of bacteria on metal coupon, first, mild steel coupons $(10 \mathrm{~mm} \times 10 \mathrm{~mm} \times 1 \mathrm{~mm}$ dimensions) were polished with 240 and 400 grit polishing paper. Then, they were rinsed three times with distilled water, degreased with acetone, and sterilized by immersing in ethanol solution before exposing to the experimental media. Each coupon placed into $50 \mathrm{ml}$ container which was filled with artificial seawater medium $(24.6 \mathrm{~g} \mathrm{NaCl}, 0.67 \mathrm{~g}$ $\mathrm{KCl}, 1.36 \mathrm{~g} \mathrm{CaCl}_{2} \cdot 2 \mathrm{H}_{2} \mathrm{O}, 6.29 \mathrm{~g} \mathrm{MgSO}_{4} \cdot 7 \mathrm{H}_{2} \mathrm{O}, 4.66 \mathrm{~g}$ $\mathrm{MgCl}_{2} \cdot 6 \mathrm{H}_{2} \mathrm{O}, 0.18 \mathrm{~g} \mathrm{NaHCO}_{3}$ in 11 of distilled water, and $\mathrm{pH}$ 7.5-8.0) containing $3 \mathrm{~g} / \mathrm{l}$ peptone as carbon and energy source. In all the bottles except controls, late-exponential phase culture of bacteria $(1 \% \mathrm{v} / \mathrm{v})$ has been inoculated. The flasks were incubated at $27^{\circ} \mathrm{C}$ in anaerobic condition for $48 \mathrm{~h}$. After incubation, coupons were taken out from the container and rinsed with sterile distilled water to remove the planktonic bacteria and cultural debris. Then, metal coupons were placed in a new screw cap container filled with $10 \mathrm{ml}$ ethanol. After $20 \mathrm{~min}$ fixation, ethanol was discarded and metal pieces were air dried and stained for 15 min with $0.1 \%$ crystal violet. Coupons were then rinsed thoroughly, air dried, and then destained using $95 \%$ ethanol. After $30 \mathrm{~min}$ incubation in alcohol solution, $100 \mu \mathrm{l}$ of the dissolved solution were transferred to the wells of 96-well plates, and the optical density (OD) of each well was measured at $570 \mathrm{~nm}$ using a microtiter plate reader. Sterile medium was used as control in each condition.

\section{Corrosion test}

To analyse and compare the effect of each isolates on the metal corrosion, weight loss test was carried out. For this test, first, mild steel coupons $(50 \mathrm{~mm} \times 20 \mathrm{~mm} \times 1 \mathrm{~mm}$ dimensions) were prepared as explained above and placed in artificial medium. Then, each coupon placed into container which was filled with 11 artificial seawater medium. Later, bacteria inoculated in all the bottles except controls. The flasks were incubated at $25{ }^{\circ} \mathrm{C}$ for 15 days, and then, they were sampled. Coupons were scraped using a sterile scalpel to remove bacterial biofilm. For the mass loss test, coupons were cleaned by washing in acid, neutralizing with sodium bicarbonate, rinsing in water and acetone, and drying in an air stream (Nemati et al. 2001). The weight loss was calculated by subtracting the weight of each coupon which was measured by a digital balance before starting the test and after cleaning of each coupon at the end of the incubation period. Later, the corrosion rate of metal coupons with $8.96 \mathrm{~g} / \mathrm{cm}^{3}$ density was calculated using the following formula (Ghafari et al. 2013):

$C=(534 W / D A T) \times 0.0254$, where $C$ is the corrosion rate ( $\mathrm{mm} / \mathrm{year}), W$ is the mass loss of the coupons $(\mathrm{mg}), D$ is the density of sample $\left(\mathrm{g} / \mathrm{cm}^{3}\right)$, $A$ is the area of sample (in. ${ }^{2}$ ), and $T$ is exposure time (h). Medium replenishment was done every 7 days. The experiments have been done in triplicate.

\section{Result and discussion}

Seawater contains the variety of oxidized sulfur compounds with sulfate being the most predominant. Sulfate can be utilized by assimilatory and dissimilatory sulfatereducing bacteria. While in assimilatory sulfate reduction, small amounts of sulfate are reduced to $\mathrm{H}_{2} \mathrm{~S}$ intra-cellularly for the synthesis of cellular material, dissimilatory sulfate reducers utilize sulfate in large scale for the production of energy, and they secrete copious amounts of sulfide from the cell (Batzer and Sharitz 2014).

Dissimilatory sulfate reducers or SRB are one of the well-known bacteria associated with microbiologically influenced corrosion process. Though these bacteria exist extensively in seawater, they only become a problem when they proliferate on the metal of ship hull docked in polluted environment (Enning and Garrelfs 2014). Therefore, it is important to use biocide for controlling SRB growth. Since the selection of appropriate and effective biocide is dependent on the type of organisms, in the present study, biofilm formed on five different zone of corroded ship hull was used for isolation of sulfate-reducing bacteria. After the enrichment and plating of the bacteria on specific SRB media, one representative of morphologically distinct bacterial type from each sample was randomly selected and used for further studies.

\section{S rDNA based identification}

The composition of SRB communities isolated from corroded samples collected from hull of ship was determined by the sequencing of the $16 \mathrm{~S}$ rDNA gene. All the ten sequences were submitted to GenBank, NCBI (National Center for Biotechnology Information), and their accession numbers plus their systematic position are presented in Table 1. The sequences which were submitted to BLAST search for retrieving the corresponding phylogenetic relatives showed that all the isolates are having above $97 \%$ similarity to the closely related bacteria. Based on the sequence obtained, a neighbor-joining phylogenetic tree was constructed to visualize the relationship among the isolated strains of the biofilm (Fig. 1). The tree contains two major clades; one consisting of members of common sulfate-reducing bacteria belongs to class Deltaproteobacteria and Clostridia and the other consisting of bacteria belongs to class Gammaproteobacteria. 
Table 1 Systematic positions of the isolated SRB from biofilm formed on corroded ship hull

\begin{tabular}{|c|c|c|c|c|c|c|c|}
\hline Assigned code & Sample no. & Phylum & Class & Order & Genus & Species & $\begin{array}{l}\text { GenBank } \\
\text { accession no. }\end{array}$ \\
\hline GSR1 & 1 & Proteobacteria & Gammaproteobacteria & Enterobacteriales & Citrobacter & freundii & KT368814 \\
\hline GSR3 & 3 & Proteobacteria & Deltaproteobacteria & Desulfovibrionales & Deulfovibrio & marinisediminis & KR303707 \\
\hline GSR4 & 1 & Proteobacteria & Deltaproteobacteria & Desulfovibrionales & Desulfovibrio & marinisediminis & KR349309 \\
\hline GSR 14 & 5 & Firmicutes & Clostridia & Clostridiales & Desulfotomaculum & intricatum & KT223435 \\
\hline GSR15 & 2 & Proteobacteria & Deltaproteobacteria & Desulfovibrionales & Desulfovibrio & marinisediminis & KR349310 \\
\hline GSR 17 & 5 & Proteobacteria & Deltaproteobacteria & Desulfovibrionales & Desulfovibrio & marinisediminis & KT373802 \\
\hline GSR 19 & 5 & Proteobacteria & Deltaproteobacteria & Desulfovibrionales & Desulfovibrio & senezii & KT373804 \\
\hline GSR21 & 2 & Proteobacteria & Gammaproteobacteria & Enterobacteriales & Citrobacter & freundii & KT368815 \\
\hline GSR33 & 3 & Proteobacteria & Gammaproteobacteria & Enterobacteriales & Citrobacter & freundii & KT368816 \\
\hline GS21 & 4 & Proteobacteria & Deltaproteobacteria & Desulfovibrionales & Desulfovibrio & Marinisediminis & KR094971 \\
\hline
\end{tabular}

Fig. 1 Phylogenetic tree of partial 16S rDNA obtained from corrosive biofilm on ship hull

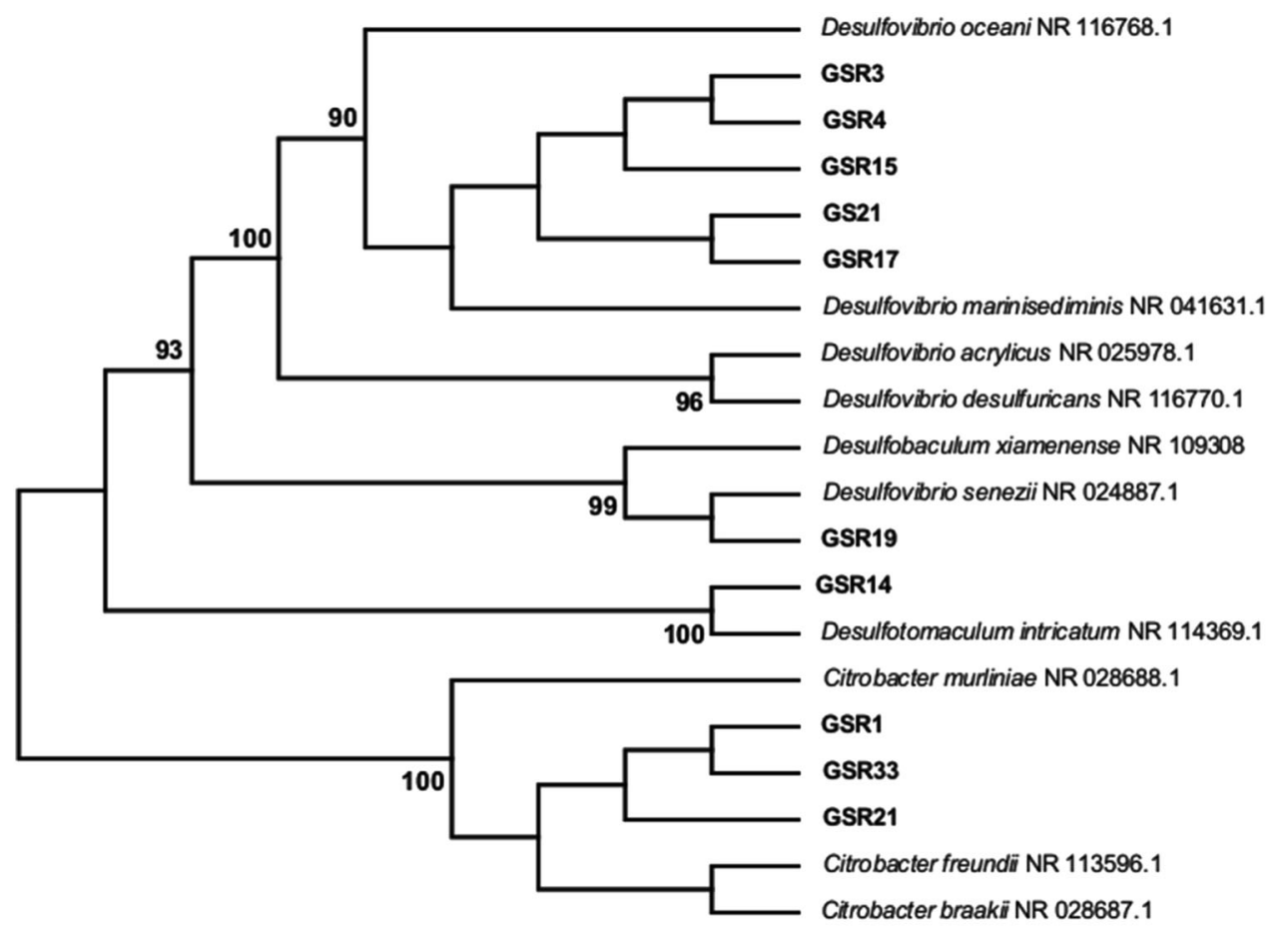

Within Deltaproteobacteria, five isolates showed a strong similarity $(99.9 \%)$ with Desulfovibrio marinisediminis C/L2 (NR 041631) and one isolate showed $99 \%$ similarity with $D v$. senezii. Desulfovibrio were the most frequent group among isolated SRB (five Dv. marinisediminis isolates from five different samples and one $D v$. Senezii isolate from sample no. 5). This result can be explained by the easy and rapid growth of Desulfovibrio which excludes other SRBs while competing for the same substrate. Laanbroek et al. (1984) reported that Desulfovibrio have higher affinity for sulfate compared to Desulfobulbus and Desulfobacter spp. and the former can out-compete the latter when the amount of sulfate available is limited. Desulfovibrio are anaerobic cells with high oxygen-tolerance (Sass and Cypionka 2007). This could be another reason for their isolation from the uppermost sample (with the highest oxygen exposure) to lowermost one (with least exposure to the oxygen). Desulfovibrio have been isolated previously from corroded hull of an oil storage vessel and copper piping system of a surface ship (Feio et al. 1998).

Sample no. 5 which was taken from the bottom part of the hull contained one isolate belonged to Clostridia and it 
showed $100 \%$ similarity to Dt. intricatum SR45. Though bacteria belonging to Desulfotomaculum are commonly isolated from freshwater or habitats with relatively low salt concentration, there are reports regarding their isolation from marine environment (Isaksen et al. 1994; Nilsen et al. 1996). Desulfotomaculum spp. were also isolated from the industrial environment, such as cooling tower and crude oil field (Anandkumar et al. 2009; Cetin and Aksu 2009).

The class Gammaproteobacteria had three isolates which were belonging to the Enterobacteriales order and all were showing high degree of similarity (99-100\%) to Citrobacter freundii. There are several reports from the isolation of these bacteria from corroded samples along with SRB bacteria (Neria-Gonzalez et al. 2006; Bermont-Bouis et al. 2007; Agrawal et al. 2010). The isolated Citrobacter was present in sample 1-3; samples which were exposed to higher oxygen concentration. Citrobacter is facultative anaerobic bacteria, and they are associated with Enterobacteriaceae family. Sulfide production is wide spread among Enterobacteriaceae. However, Citrobacter is the only organism which can reduce sulfate. Angeles-Ch et al. (2002) isolated a strain of Citrobacter amalonaticus from the corroded gas pipeline. They mentioned that this strain of Citrobacter is able to reduce sulfate to sulfide. The isolation of bacteria belongs to C. freundii with sulfate reduction capability shows that the diversity of SRB still has the possibility to be expanded (Zhang et al. 2015; Zhou et al. 2015).

\section{Sulfate reduction and sulfide production}

Though the cultural and molecular results indicating the presence of Citrobacter spp. with sulfate reduction ability, to ensure the accuracy of the results, more experiments are carried out by emphasizing on hallmark characteristic of dissimilatory sulfate-reducing bacteria (i.e., consumption of high amount of sulfate and production of copious amount of sulfide). Figure 2 shows the amount of sulfate reduced and sulfide produced by each isolates. As expected high sulfate reduction was the character seen in all the traditional SRB. Strain GSR1, GSR21, and GSR33 reduced $8.5,6.2$, and $9.7 \mathrm{mM}$ of sulfate, respectively.

Bacteria produced 7-11 mM sulfide. The highest concentration of sulfide $(11 \mathrm{mM})$ has been produced by $D v$. marinisedimins GSR3 and GSR17, and the least amount of sulfide ( $7 \mathrm{mM}$ ) was produced by $C$. frundii GSR21. Sulfide produced by all the three non-traditional SRB was less compared to the amount of sulfide produced by the traditional SRB. However, the amount of sulfide produced in the test was sufficient to consider these strains of Citrobacter as sulfate-reducing bacteria.

Zhou et al. (2015) have reported the isolation of $C$. frundii from the sludge of a paper mill located in Tianjin, China. This bacterium reduced $12 \mathrm{mM}$ of sulfate within 7 days. In another study, Qiu et al. (2009) isolated another species of Citrobacter (with $98 \%$ similar to $C$. freundii, $C$. braakii, and $C$. werkmanii) from mining area with good sulfate reduction potential (this strain produced $4 \mathrm{mM}$ sulfide). Due to the production of high amount of sulfide, they suggested that sulfate reduction by this bacterium could be through dissimilatory pathway.

\section{Amplification of $\operatorname{dsr} A B$ gene}

Since the isolated Citrobacter was able to produce hydrogen sulfide, while sulfate was the only sulfur compound in the media, we tried to find out whether Citrobacter are also
Fig. 2 Utilization of sulfate (white) and production of hydrogen sulfide (black) by isolated bacteria

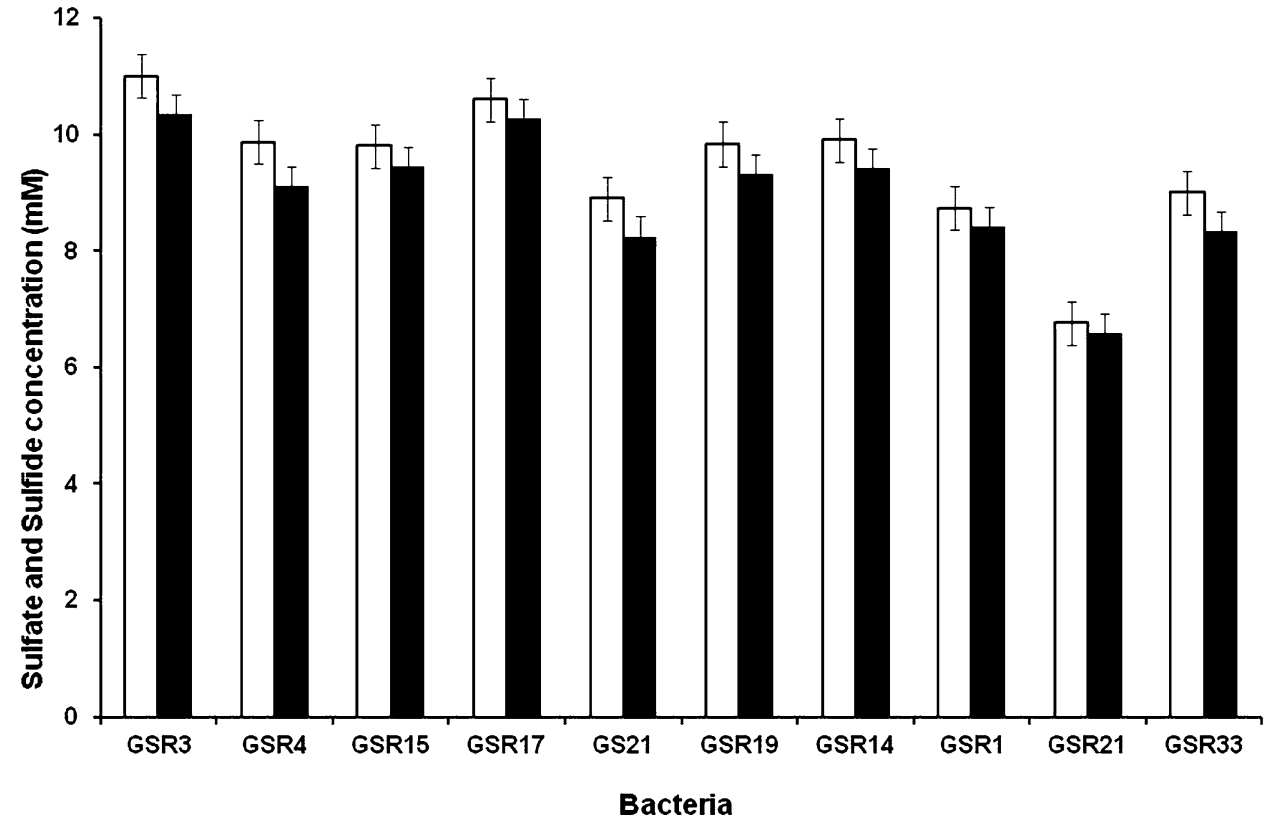

Bacteria

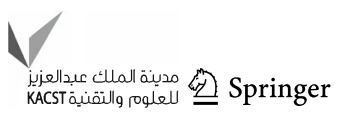




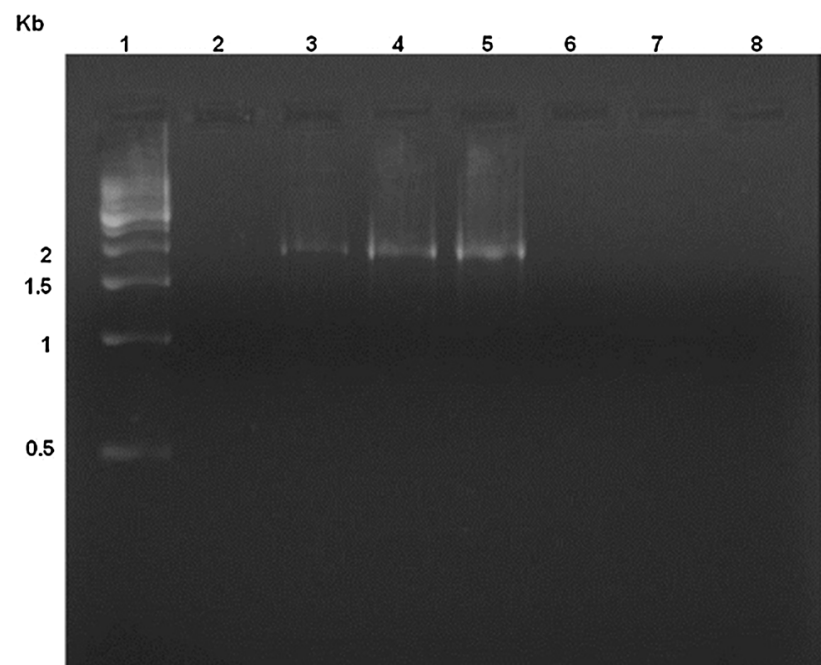

Fig. 3 Amplification of $d s r A B$ gene using DSR1F-DSR4R with genomic DNA from Citrobacter freundii GSR1 (lane 2), Desulfovibrio marinisediminis GSR3 (lane 3), Desulfovibrio senezii GSR19 (lane 4), Desulfotomaculum intricatum GSR14 (lane 5), Citrobacter freundii GSR21 and GSR33 (lanes 6 and 7), and Escherichia coli MTCC40 (lane 8). Lane 1 represents the 500 bp DNA ladder

reducing sulfate through dissimilatory pathway by checking the presence of $d s r A B$ gene.

$d s r A B$ gene encodes the dissimilatory sulfite reductase, an enzyme that catalyzes the six-electron reduction of sulfite to sulfide during anaerobic respiration (Wagner et al. 1998). Wagner et al. (1998) demonstrated that primer pairs DSR1 and DSR4 are specific for the $d s r A B$ gene encoding enzyme which has the ability to reduce sulfate. Using $d s r A B$ marker gene, bacteria have been divided into two groups; those containing $d s r A B$ gene (or traditional SRB)
(Dv. marinisediminis strain GSR3, GSR4, GSR15, GS21, GSR14, GSR17,GSR20, Dv. senezii GSR19, and also Dt. intricatum strain GSR14) and others which did not contain the same gene (or non-traditional SRB) (C. freundii strain GSR1, GSR21, and GSR33) (Fig. 3). Yang et al. (2010) isolated a sulfate-reducing Citrobacter sp. (Strain SR3) which contains dissimilatory sulphite reductase gene. However, all the three isolated Citrobacter in our study were lacking these genes which indicate that the isolated Citrobacter spp. may have some other strategies for sulfate reduction.

\section{Biofilm formation on metal}

After observing the sulfate reduction ability of isolated Citrobacter spp., we investigated the corrosion potential of them in comparison with the traditional SRB. Since the effect of bacteria on corrosion depends on both biofilm formation ability and their metabolic byproduct, we first examined their biofilm forming ability. The result of this experiment showed stronger biofilm formation in Gramnegative isolates (Desulfovibrio spp. and Citrobacter spp.) compared to the Gram-positive Dt. intricatum (Figs. 4, 5). The difference between the biofilm formations of the bacteria could be explained by the chemical composition of their cell wall. In general, Gram-negative bacteria contain more anionic group in their cell wall which help in the binding of them to the cationic metal surface ( $\mathrm{Li}$ and Logan 2004). Among the Gram-negative bacteria, Citrobacter spp. produced stronger biofilm compared to the Desulfovibrio spp. The members of Enterobacteriaceae family are well known as common colonizers on metal surfaces
Fig. 4 Biofilm forming ability of isolated bacteria after $48 \mathrm{~h}$ incubation in anaerobic condition

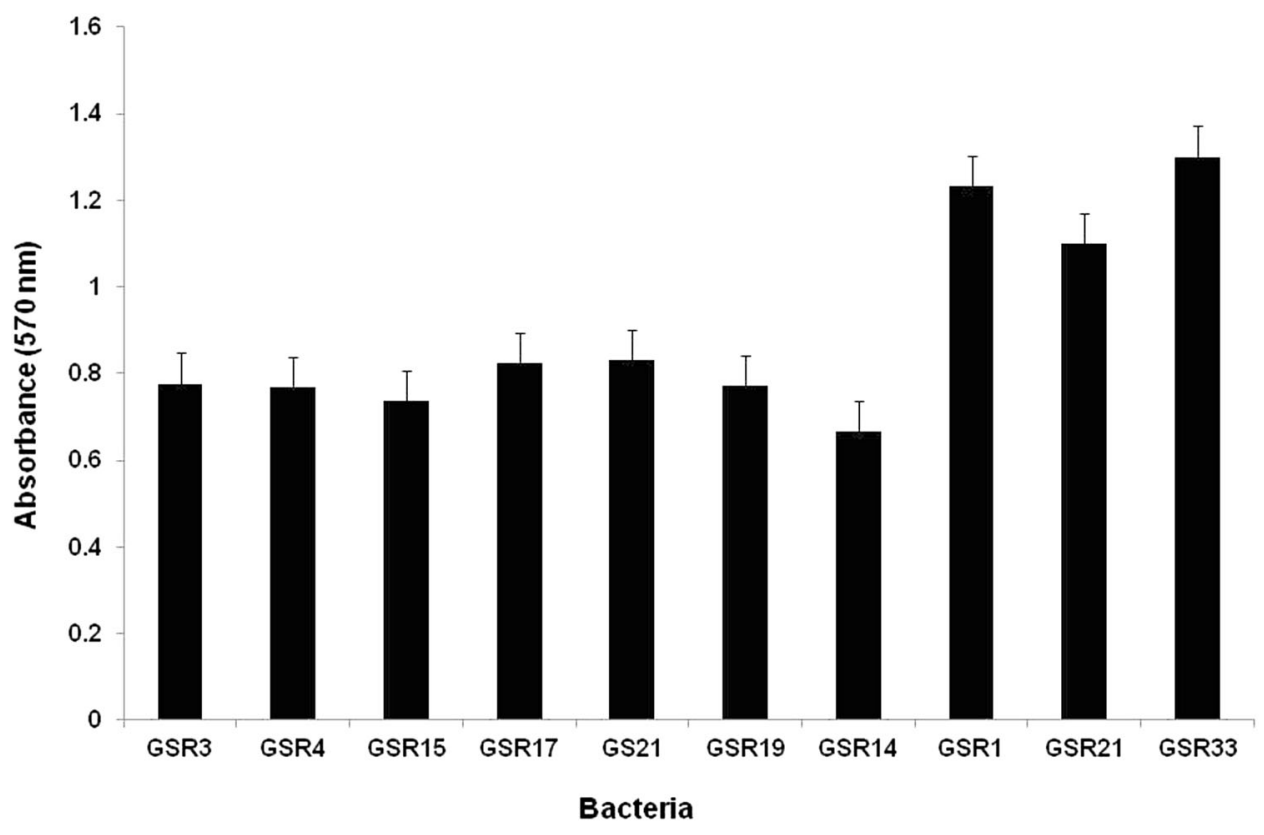


Fig. 5 Formation of biofilm by the isolated bacteria differentiated by crystal violate staining in 96 well plates (well No. 1-10 shows the biofilm formation by following strain; GSR3, GSR4, GSR15, GSR17, GS21, GSR19, GSR14, GSR1, GSR21, and GSR33. Well no. 11 is negative control)

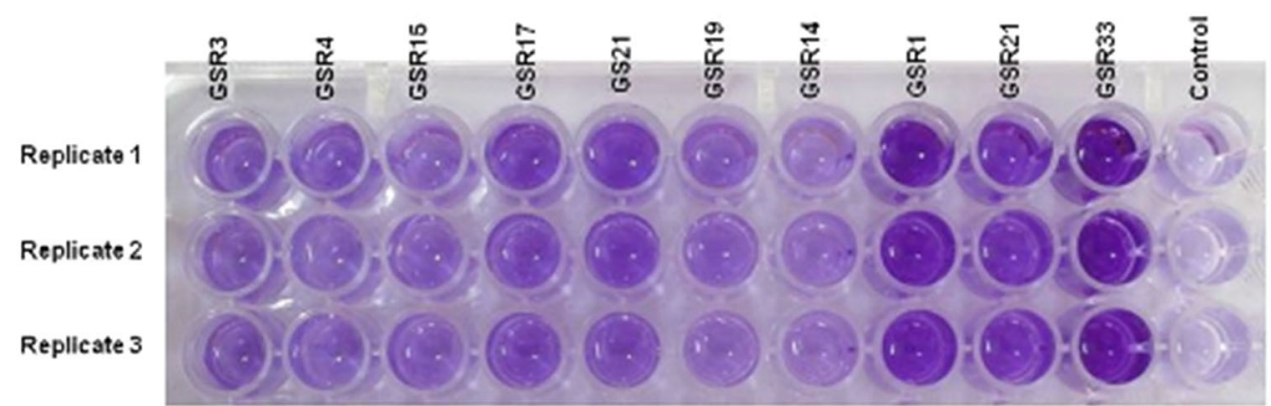

Table 2 Corrosion rates of mild steel coupons exposed to different isolates

\begin{tabular}{|c|c|c|c|c|c|c|c|c|c|c|c|}
\hline \multirow[t]{2}{*}{ Bacteria } & \multicolumn{5}{|c|}{ Dv. marinisediminis } & \multirow{2}{*}{$\begin{array}{l}\text { Dv. senezii } \\
\text { GSR19 }\end{array}$} & \multirow{2}{*}{$\begin{array}{l}\text { Dt. intricatum } \\
\text { GSR14 }\end{array}$} & \multicolumn{3}{|c|}{ C. freundii } & \multirow[t]{2}{*}{ Control } \\
\hline & GSR3 & GSR4 & GSR15 & GSR17 & GS21 & & & GSR1 & GSR21 & $\overline{\text { GSR33 }}$ & \\
\hline Corrosion rate (mm/year) & 0.3837 & 0.37451 & 0.3654 & 0.3759 & 0.379 & 0.2512 & 0.3735 & 0.1435 & 0.1207 & 0.1434 & 0.0014 \\
\hline
\end{tabular}

(Bermont-Bouis et al. 2007). In the early stage of biofilm formation, they produce extracellular polymeric substances which facilitate the attachment of other microorganism (Jan-Roblero et al. 2004; Neria-Gonzalez et al. 2006; Bermont-Bouis et al. 2007).

\section{Corrosion rate}

After studying the sulfide production and biofilm formation of each isolate, the influence of these bacteria on metal corrosion was also studied by the mass loss method. In this test, all ten isolates showed a significant weight loss in mild steel compared to the control (Table 2). Corrosion caused by the traditional SRB was higher than the non-traditional one. Dv. marinisediminis GSR3 which produced the highest hydrogen sulfide showed the highest mass loss (0.3837 mm/year), and the lowest mass loss was observed in $C$. freundii GSR21 (0.1207 mm/year).

In the conclusion, using the cultural method, we isolated ten bacteria, in which three were having unusual sulfate metabolism. The chance of finding species with a novel metabolic activity among hull fouling bacteria is high because of their diverse microbial habitat. They are exposed to a wide range of environment from oceanic waters to contaminated harbor. Therefore, their survival requires constant adaptations to various conditions which lead to the development of multiple pathways ( $\mathrm{Fu}$ et al. 2004). Though the three isolated Citrobacter spp. were less aggressive compared to the traditional SRB, their corrosion potential was highly significant. In view of the fact that the isolated facultative SRB, such as Citrobacter spp., have aerobic respiration, and they can multiply rapidly in such an condition, it is important to consider their role while studying MIC, because large numbers of these facultative SRB could create severe MIC under anaerobic condition.

\section{Nucleotide sequence accession numbers}

The accession numbers given to all the ten sequences were submitted to GenBank, NCBI is as follows: KT368814, KR303707, KR349309, KT223435, KR349310, KT373802, KT373804, KT368815, KT368816, and KR094971.

\section{Compliance with ethical standards}

Conflict of interest The authors declare that they have no conflict of interest in the publication.

Open Access This article is distributed under the terms of the Creative Commons Attribution 4.0 International License (http:// creativecommons.org/licenses/by/4.0/), which permits unrestricted use, distribution, and reproduction in any medium, provided you give appropriate credit to the original author(s) and the source, provide a link to the Creative Commons license, and indicate if changes were made.

\section{References}

Agrawal A, Vanbroekhoven K, Lal B (2010) Diversity of culturable sulfidogenic bacteria in two oil-water separation tanks in the north-eastern oil fields of India. Anaerobe 16:12-18

Almeida E, Diamantino TC, de Sousa O (2007) Marine paints: the particular case of antifouling paints. Prog Org Coat 59:2-20

Anandkumar B, Choi JH, Venkatachari G, Maruthamuthu S (2009) Molecular characterization and corrosion behavior of thermophilic (55 C) SRB Desulfotomaculum kuznetsovii isolated from cooling tower in petroleum refinery. Mater Corros 60:730-737

Angeles-Ch C, Mora-Mendoza JL, Garcia-Esquivel R, PadillaViveros AA, Perez R, Flores R, Martinez R (2002) Microbiologically influenced corrosion by Citrobacter in sour gas pipelines. Mater Perform 41:50-55

Batzer DP, Sharitz RR (eds) (2014) Ecology of freshwater and estuarine wetlands. University of California Press, Berkeley 
Beech IB, Sunner J (2004) Biocorrosion: towards understanding interactions between biofilms and metals. Curr Opin Biotechnol 15:181-186

Bermont-Bouis D, Janvier M, Grimont PAD, Dupont I, Vallaeys T (2007) Both sulfate-reducing bacteria and Enterobacteriaceae take part in marine biocorrosion of carbon steel. J Appl Microbiol 102:161-168

Bodtker G, Thorstenson T, Lillebo BLP et al (2008) The effect of long-term nitrate treatment on SRB activity, corrosion rate and bacterial community composition in offshore water injection systems. J Ind Microbiol Biotechnol 35:1625-1636

Cetin D, Aksu ML (2009) Corrosion behavior of low-alloy steel in the presence of Desulfotomaculum sp. Corros Sci 51:1584-1588

Cord-Ruwisch R (1985) A quick method for the determination of dissolved and precipitated sulfides in cultures of sulfate-reducing bacteria. J Microbiol Methods 4:33-36

Enning D, Garrelfs J (2014) Corrosion of iron by sulfate-reducing bacteria: new views of an old problem. Appl Environ Microbiol 80:1226-1236

Feio MJ, Beech IB, Carepo M et al (1998) Isolation and characterisation of a novel sulphate-reducing bacterium of the Desulfovibrio genus. Anaerobe 4:117-130

Fu X, Wang D, Yin X, Du P, Kan B (2004) Time course transcriptome changes in Shewanella algae in response to salt stress. PloS one 9:1-8.

Ghafari MD, Bahrami A, Rasooli I, Arabian D, Ghafari F (2013) Bacterial exopolymeric inhibition of carbon steel corrosion. Int Biodeterior Biodegrad 80:29-33

Gilcreas FW (1965) Simplified procedures for water examination. Am J Public Health Nations Health 55:1109-1110

Inbakandan D, Sriyutha MP, Venkatesan R, Ajmal KS (2010) 16 S rDNA sequence analysis of culturable marine biofilm forming bacteria from a ship's hull. Biofouling 26:893-899

Isaksen MF, Bak F, Jorgensen BB (1994) Thermophilic sulfatereducing bacteria in cold marine sediment. FEMS Microbiol Ecol 14:1-8

Jakubowski M (2011) Influence of pitting corrosion on strength of steel ships and offshore structures. Pol Marit Res 18:54-58

Jan-Roblero J, Romero JM, Amaya M, Le Borgne S (2004) Phylogenetic characterization of a corrosive consortium isolated from a sour gas pipeline. Appl Microbiol Biotechnol 64:862-867

Laanbroek HJ, Geerligs HJ, Sijtsma L, Veldkamp H (1984) Competition for sulfate and ethanol among Desulfobacter, Desulfobulbus, and Desulfovibrio species isolated from intertidal sediments. Appl Environ Microbiol 47:329-334
Lane DJ (1991) 16S/23S rRNA sequencing. In: Stackebrandt E, Goodfellow $M$ (eds) Nucleic acid techniques in bacterial systematic. Wiley, Chichester, pp 115-175

Li B, Logan BE (2004) Bacterial adhesion to glass and metal-oxide surfaces. Colloids Surf B Biointerfaces 36:81-90

Licina GJ, Cubicciotti D (1989) Microbial-induced corrosion in nuclear power plant materials. JOM 41:23-27

Nemati T, Jenneman GE, Voordouw G (2001) Impact of nitratemediated microbial control of souring in oil reservoirs on the extend of corrosion. Biotechnol Prog 17:852-859

Neria-Gonzalez I, Wang ET, Ramírez F, Romero JM, HernándezRodríguez C (2006) Characterization of bacterial community associated to biofilms of corroded oil pipelines from the southeast of Mexico. Anaerobe 12:122-133

Nilsen RK, Torsvik T, Lien T (1996) Desulfotomaculum thermocisternum sp. nov., a sulfate reducer isolated from a hot North Sea oil reservoir. Int J Syst Evol Microbiol 46:397-402

Qiu R, Zhao B, Liu J et al (2009) Sulfate reduction and copper precipitation by a Citrobacter sp. isolated from a mining area. J Hazard Mater 164:1310-1315

Sass H, Cypionka H (2007) Response of sulphate-reducing bacteria. In: Barton LL, Hamilton WA (eds) Sulphate-reducing bacteria: environmental and engineered systems. Cambridge University Press, Cambridge, pp 167-185

Schultz MP, Bendick JA, Holm ER, Hertel WM (2011) Economic impact of biofouling on a naval surface ship. Biofouling 27:87-98

Tsinker GP (2004) Port engineering: planning, construction, maintenance, and security. Wiley, New Jersey

Wade SA, Mart PL, Trueman AR (2011) Microbiologically influenced corrosion in maritime vessels. Corros Mater 36:68-79

Wagner M, Roger AJ, Flax JL, Brusseau GA, Stahl DA (1998) Phylogeny of dissimilatory sulfite reductases supports an early origin of sulfate respiration. J Bacteriol 180:2975-2982

Yang LP, Zheng XH, Zeng GQ, Xu MY, Sun GP (2010) Isolation and characterization of a sulfate reducing Citrobacter sp. strain SR3. Huan Jing Ke Xue 31:815-820

Zhang Q, He Y, Wang W, Lin N, Wu C, Li N (2015) Corrosion behavior of WC-Co hardmetals in the oil-in-water emulsions containing sulfate reducing Citrobacter sp. Corros Sci 94:48-60

Zhou W, Yang M, Song Z, Xing J (2015) Enhanced sulfate reduction by Citrobacter sp. coated with $\mathrm{Fe}_{3} \mathrm{O}_{4} / \mathrm{SiO}_{2}$ magnetic nanoparticles. Biotechnol Bioprocess Eng 20:117-123 